\title{
Aplikasi Berbagai Komposisi dan Konsentrasi Pupuk Majemuk untuk Pembentukan Kantong pada Nepenthes $\mathrm{x}$ ventrata
}

\section{The Effect of Fertilizer Application on Growth and Pitcher Formation of Nepenthes $x$ ventrata}

\author{
Romy Agus Saputro, Sintho Wahyuning Ardie*, Krisantini
}

Departemen Agronomi dan Hortikultura, Fakultas Pertanian, Institut Pertanian Bogor (Bogor Agricultural University), Jl. Meranti, Kampus IPB Darmaga, Bogor 16680, Indonesia

Telp.\&Faks.62-251-8629353 e-mail agronipb@indo.net.id

\begin{abstract}
Nepenthes is a genus of carnivorous plants in the monotypic family Nepenthaceae. The genus comprises around 130 species, numerous natural and many cultivated hybrids. Plants generally need fertilizer to promote their growth and development. However, in their original habitat Nepenthes forms pitchers under nutrition starvation condition. This study aimed at determining the effect of fertilization on the growth and pitcher formation of Nepenthes $x$ ventrata. Experiment was conducted at Suska Nursery, Caringin, West Java, Indonesia from February until June 2011. Plants were treated with the N: P: K, 60-30-30, 32-10-10 and 10-55-10 and at different concentrations ie, $0.5,1$ and $2 \mathrm{~g} \mathrm{~L}^{-1}$. Fertilizer was applied weekly to the growing media. Weekly observations were conducted on number of leaves, plant height, time of pitchers initiation, the number of pitchers and pitcher diameter and length. Daily temperature, relative humidity and EC (electrical conductivity) of the growing media were also recorded during the experiment. The results showed that combination of fertilizer with different composition and concentration did not affect Nepenthes growth and development. Application of fertilizer resulted in smaller size pitchers compared to control plants. Future research on Nepenthes should be conducted in a longer period since Nepenthes is a slow growing plants.
\end{abstract}

Keywords: Nepenthes $x$ ventrata, fertilizer, pitcher plant

\section{ABSTRAK}

Nepenthes adalah satu-satunya genus tanaman karnivora dalam keluarga Nepenthaceae. Genus ini terdiri dari sekitar 130 spesies, yang tumbuh alamai dan banyak dibudidayakan secara hibrida. Tanaman pada umumnya membutuhkan pupuk untuk meningkatkan pertumbuhan dan perkembangannya. Namun, pada habitat aslinya, Nepenthes membentuk kantong dalam kondisi miskin hara. Penelitian ini bertujuan untuk mengetahui pengaruh pemupukan NPK terhadap pertumbuhan dan pembentukan kantong Nepenthes $x$ ventrata. Penelitian dilakukan di Suska Nursery, Caringin, Jawa Barat, Indonesia dari bulan Februari sampai Juni 2011. Perlakuan tanaman dengan N: P: K, 60-30-30 32-10-10 10-55-10 dan pada konsentrasi yang berbeda yaitu, 0,5, 1 dan 2 $g$ L-1. Pupuk diaplikasikan ke media tanam setiap minggu. Pengamatan mingguan dilakukan pada jumlah daun, tinggi tanaman, waktu muncul (inisiasi) kantong pertama, jumlah kantong, serta diameter dan panjang kantong. Suhu harian, kelembaban relatif dan EC (konduktivitas listrik) dari media tanam juga dicatat selama penelitian. Hasil penelitian menunjukkan bahwa kombinasi pupuk dengan komposisi yang berbeda dan konsentrasi tidak mempengaruhi pertumbuhan dan perkembangan Nepenthes. Penerapan pupuk mengakibatkan ukuran kantong yang lebih kecil dibandingkan dengan tanaman kontrol. Penelitian yang akan dating, Nepenthes harus dilakukan dalam jangka waktu lama karena Nepenthes adalah tanaman yang tumbuh lambat.

Kata kunci : Nepenthes $x$ ventrata, pupuk, tanaman kantong

* Penulis untuk korespondensi. e-mail: sinthoardie@gmail.com 


\section{PENDAHULUAN}

Kantong semar (Nepenthes sp.) ialah tanaman yang termasuk dalam golongan tanaman perangkap. Tanaman ini juga biasa dikenal sebagai tanaman karnivora karena dapat menjadi perangkap sekaligus pemangsa serangga. Nepenthes semar tersebar dari Madagaskar, Seychelles, India, Srilangka, Indocina, Cina Selatan, Semenanjung Malaysia, Filipina, Indonesia, Australia bagian Utara hingga kepulauan di Pasifik (Phillips, 2008). Nepenthes merupakan satu-satunya genus dalam keluarga Nepenthaceae. Perbanyakan tanaman Nepenthes dilakukan melalui stek batang, biji, dan pemisahan anakan. Umumnya Nepenthes yang hidup di dataran rendah tumbuh di tempat-tempat yang berair atau dekat sumber air pada substrat yang bersifat masam, membutuhkan cahaya matahari intensif dengan panjang siang hari antara 1012 jam setiap hari sepanjang tahun, kelembaban yang cukup tinggi berkisar dari 70-90\% dengan suhu $25-$ $35^{\circ} \mathrm{C}$ (Clarke, 1997). Nepenthes merupakan tanaman tahunan yang dapat tumbuh menjalar, merambat, ataupun berbentuk perdu. Nepenthes sangat menarik untuk diteliti karena jenis tersebut digolongkan ke dalam tanaman hias unik, seperti halnya tanaman karnivora lainnya.

Selain unik, Nepenthes termasuk dalam daftar CITES (Convention on International Trade Endangered Species of Wild Flora and Fauna), yang terdapat pada apendix I, II, dan III yang keberadaanya terancam kepunahan (Hernawati dan Akhriadi, 2006). Semua jenis Nepenthes dilindungi di habitat aslinya. Nepenthes yang boleh diperdagangkan adalah yang merupakan hasil dari penangkaran dan bukan yang berasal dari habitat aslinya, sehingga tanaman yang tergolong langka ini sudah mulai dikembangkan secara ex-situ dan ditangkarkan. Oleh karena itu para penggemar maupun penyilang mulai banyak mengembangkan Nepenthes hibrida yang lebih tahan terhadap cekaman lingkungan jika tidak sesuai dengan lingkungan tempat hidupnya. Salah satunya yaitu Nepenthes $x$ ventrata yaitu silangan dari $N$. alata dan $N$. ventricosa. Nepenthes jenis ini memiliki kantong yang cukup panjang dan hidup secara epifit dengan menjulur dan merambat pada pohon. Nepenthes $x$ ventrata juga merupakan jenis Nepenthes yang mudah dikembangbiakkan. Kantong dari Nepenthes $x$ ventrata juga biasa digunakan sebagai kantong potong setelah kering dengan penggunaan pewarna dan zat pengawet sebagai aksen lain pendamping bunga potong.

Kantong pada Nepenthes terbentuk dari bagian daun yang termodifikasi menjadi perangkap mangsa seperti serangga maupun hewan kecil lainnya.
Daun yang termodifikasi menjadi kantong terdiri dari sulur, tutup, sayap dan bagian lubang yang terdiri dari zona lilin dan kelenjar pencernaan yang dapat melumat serangga dan menyerap nutrisi yang ada di dalamnya (Wang, 2007). Menurut Phillips et al. (2008), serangga akan tertarik pada cairan nektar pada bagian bibir kantong, penutup kantung dan pada zona lilin yang licin sehingga terperangkap ke dalam zona pencernaan yang mengandung enzim pencernaan yang kental. Mansur (2007) menambahkan bahwa enzim pencernaan Nepenthes sp. disebut proteolase yang akan mengubah serangga yang terperangkap menjadi zat-zat yang lebih sederhana. Oleh karena itu, Nepenthes dapat hidup pada daerah yang sangat miskin hara karena sudah mendapatkan nutrisi seperti protein dan mineral dari serangga yang terperosok ke dalamnya (Budiana, 2007). Pada beberapa tanaman karnivora pemberian pupuk dapat meningkatkan pertumbuhan dibandingkan dengan tanaman yang tidak diberi pupuk tambahan (Adamec, 1997), dan pada N. talangensis, pemupukan dapat meningkatkan kandungan $\mathrm{N}$ pada daun, laju fotosintesis, dan biomassa tanaman (Pavlovic et al., 2010). Dalam rangka mengembangkan Nepenthes secara ex-situ, di mana ketersediaan serangga tidak sebanyak pada habitat aslinya dan kondisi lingkungan tumbuh dapat dikontrol, perlu diketahui komposisi dan konsentrasi pupuk yang optimal.

Penelitian ini bertujuan untuk mengetahui pengaruh pemupukan NPK terhadap pertumbuhan dan pembentukan kantong Nepenthes $x$ ventrata.

\section{BAHAN DAN METODE}

Penelitian ini dilaksanakan di bawah struktur naungan plastik UV di Suska Nursery, Kampung Ciderum, Caringin, Bogor pada bulan Februari 2011 sampai dengan Juni 2011.

Bahan tanaman yang digunakan dalam penelitian ini adalah tanaman Nepenthes $\mathrm{x}$ ventrata yang berasal dari stek dan telah berumur dua bulan setelah tanam (BST) serta memiliki empat ruas daun. Media tanam yang digunakan yaitu arang sekam dan cocopeat yang dicampur rata dengan perbandingan 2:1 (v/v). Pupuk yang digunakan adalah pupuk majemuk dengan komposisi NPK (6-30-30), (32-10-10), dan (10-55-10).

Rancangan penelitian yang digunakan dalam penelitian ini adalah rancangan acak lengkap (RAL) faktorial dengan dua faktor. Faktor pertama yaitu komposisi pupuk majemuk dengan tiga taraf yaitu NPK 6-30-30, 32-10-10, dan 10-55-10. Faktor kedua adalah konsentrasi pupuk majemuk dengan tiga taraf, yaitu $0.5 \mathrm{~g} \mathrm{~L}^{-1}, 1 \mathrm{~g} \mathrm{~L}^{-1}$, dan $2 \mathrm{~g} \mathrm{~L}^{-1}$. Tanaman 
yang tidak diberi pupuk digunakan sebagai kontrol. Aplikasi pupuk majemuk dilakukan dengan cara menyiramkan larutan pupuk ke media tanam setiap satu minggu sekali di pagi hari dan dilakukan tidak bersamaan dengan penyiraman untuk menghindari tercucinya pupuk. Setiap tanaman disiram dengan tiap jenis pupuk majemuk sebanyak $20 \mathrm{~mL} \mathrm{pot}^{-1}$ (kapasitas lapang per pot). Tanaman kontrol disiram air dengan volume yang sama. Pengendalian terhadap gulma yang tumbuh di sekitar tanaman dilakukan secara manual.

Pengamatan dilakukan pada semua tanaman setelah pemberian pupuk majemuk, peubah yang diamati meliputi jumlah daun, tinggi tanaman, waktu muncul (inisiasi) kantong pertama, jumlah kantong, serta diameter dan panjang kantong. Pengamatan dilakukan selama 3 bulan setelah aplikasi. Pengamatan lingkungan yang dilakukan adalah pengamatan terhadap suhu, kelembaban relatif harian dan electrical conductivity media setiap 2 minggu sekali.

Analisis data dilakukan dengan uji $\mathrm{F}$ dan apabila hasilnya berpengaruh nyata, dilakukan uji lanjut Duncan Multiple Range Test (DMRT) pada taraf $\alpha=$ $5 \%$.

\section{HASIL DAN PEMBAHASAN}

Pertumbuhan stek Nepenthes $\mathrm{x}$ ventrata sangat lambat. Stek batang Nepenthes membutuhkan waktu 8 minggu untuk membentuk akar dan memiliki daun baru. Sistem perakaran yang tidak terlalu baik umum ditemukan pada genus Nepenthes, yaitu berkembang sangat lambat (Adlassnig et al., 2005) dan dangkal (Osunkoya et al., 2007). Pada N. x superba dan N. alata yang diperbanyak menggunakan stek batang, stek membutuhkan waktu 12 minggu untuk membentuk akar (Rice, 2009).

Daya tumbuh Nepenthes $\mathrm{x}$ ventrata juga cukup rendah. Sebagian $(50 \%)$ stek yang ditanam mati sehingga hanya terdapat 50 tanaman yang tersisa dan dapat digunakan untuk diberikan perlakuan pemupukan. Suhu rata-rata harian di lokasi penelitian berkisar antara $23-25^{\circ} \mathrm{C}$ dengan kelembaban relatif berkisar antara $87-91 \%$ yang sudah sesuai dengan syarat tumbuh Nepenthes secara umum (Clarke, 1997). Rendahnya daya tumbuh tanaman diduga akibat stek yang tidak membentuk akar mati dan mengalami serangan cendawan. Pada penelitian Rice (2009), rata-rata kemampuan stek Nepenthes membentuk akar hanya sekitar $50 \%$.

\section{Pertumbuhan Vegetatif sebelum Inisiasi Kantong}

Perlakuan pupuk majemuk tidak memberikan pengaruh nyata terhadap jumlah daun pada 12 minggu setelah perlakuan (MSP), dan kenaikan tinggi tanaman pada interval 11-12 MSP (Tabel 1). Pertambahan tinggi tanaman, dan bukan tinggi tanaman absolute, diamati karena tinggi awal tanaman yang bervariasi (5-10 $\mathrm{cm})$. Rata-rata jumlah daun pada seluruh perlakuan hanya berkisar antara 2.75-6.5 helai per tanaman.

Pertumbuhan vegetatif tanaman sangat membutuhkan unsur hara, terutama nitrogen $(\mathrm{N})$ (Aminifard et al., 2010). Secara umum, pada habitat asilnya Nepenthes $s p$. memiliki kandungan $\mathrm{N}$ daun yang lebih rendah dibandingkan tanaman lain yang hidup pada habitat yang sama (Osunkoya et al., 2007), sehingga pemberian pupuk tambahan diharapkan dapat meningkatkan pertumbuhan tanaman. Pada penelitian ini, pupuk cair diaplikasikan dengan cara disiramkan ke media tanam. Cara aplikasi tersebut diduga menyebabkan unsur hara tambahan dari pupuk tidak dapat diserap dengan baik oleh tanaman mengingat perakaran Nepenthes yang kurang baik.

Hasil penelitian Schulze et al. (1997) menunjukkan bahwa sebagian besar unsur hara yang dibutuhkan $N$. mirabilis diperoleh melalui serangga yang dicerna di dalam kantongnya dan bukan dari unsur hara yang diabsorpsi akar. Pada penelitian ini, kemampuan tanaman menyerap hara diamati dengan cara memonitor EC media tanam setiap minggu setelah aplikasi pupuk. Nilai EC media tidak terlalu berbeda

Tabel 1. Pertumbuhan vegetatif pada akhir pengamatan (12 MSP)

\begin{tabular}{lccc}
\hline Perlakuan Pemupukan & $\begin{array}{c}\text { Jumlah } \\
\text { Daun } \\
\text { (helai) }\end{array}$ & $\begin{array}{c}\text { Kenaikan } \\
\text { Tinggi } \\
\text { Tanaman } \\
\text { (cm) }\end{array}$ \\
\cline { 3 - 4 } & & 5.0 & $11-12 \mathrm{MSP}$ \\
\hline Kontrol & & 3.5 & 0.6 \\
NPK & $0.5 \mathrm{~g} \mathrm{~L}-1$ & 2.8 & 0.0 \\
6/30/1930 & $1.0 \mathrm{~g} \mathrm{~L}-1$ & 4.3 & 1.3 \\
& $2.0 \mathrm{~g} \mathrm{~L}-1$ & 2.8 & - \\
NPK & $0.5 \mathrm{~g} \mathrm{~L}-1$ & 6.5 & 0.3 \\
$32-10-10$ & $1.0 \mathrm{~g} \mathrm{~L}-1$ & 5.0 & 0.9 \\
& $2.0 \mathrm{~g} \mathrm{~L}-1$ & 4.5 & 0.3 \\
NPK & $0.5 \mathrm{~g} \mathrm{~L}-1$ & 3.8 & 0.6 \\
10-55-10 & $1.0 \mathrm{~g} \mathrm{~L}-1$ & 5.0 & 1.4 \\
& $2.0 \mathrm{~g} \mathrm{~L}-1$ & $\mathrm{tn}$ & $\mathrm{tn}$ \\
\hline Uji-F & & 5
\end{tabular}

Keterangan: tn = tidak nyata; kenaikan tinggi tanaman pada perlakukan NPK 32-10-10 0.5 $\mathrm{g} \mathrm{L}^{-1}$ tidak diamati 


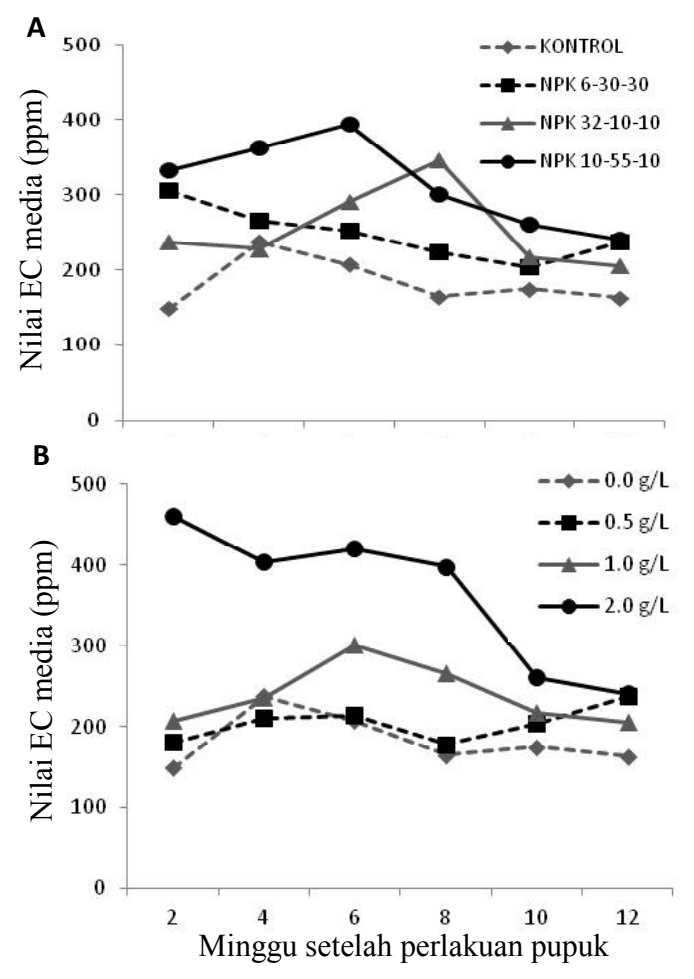

Gambar 1. Electrical conductivity (EC) media tanam Nepenthes $\mathrm{x}$ ventrata pada 2-12 MSP

antara komposisi pupuk yang berbeda, namun media tanam yang tidak diberi pupuk (kontrol) memiliki nilai EC yang lebih rendah (Gambar 1A). Sebaliknya, EC media sangat dipengaruhi oleh perbedaan kosentrasi pupuk. Media tanam yang diberi pupuk dengan konsentrasi tinggi memiliki EC media yang lebih tinggi (Gambar 1B).

Nilai EC media tidak mengalami perubahan berarti seiring dengan bertambahnya waktu penelitian, kecuali pada aplikasi pupuk dengan konsentrasi 2.0 $\mathrm{g} \mathrm{L}^{-1}$ (Gambar 1B). Hal tersebut mengindikasikan rendahnya laju penyerapan hara dari media tanam. Semakin tinggi laju serapan hara maka nilai EC akan menjadi semakin rendah.

\section{Inisiasi dan Kualitas Kantong}

Kantong pada tanaman Nepenthes merupakan modifikasi struktur daun. Pembentukan kantong diawali dengan perubahan sulur pada ujung daun yang membentuk struktur pipih sehingga disebut "kantong pipih" (Gambar 2A). Struktur tersebut dapat berkembang menjadi kantong utuh atau gagal berkembang.

Secara umum kantong utuh terbentuk pada 9 MSP pada hampir seluruh perlakuan (Gambar 3). Pada perlakuan NPK 6-30-30 dengan konsentrasi $2.0 \mathrm{~g} \mathrm{~L}^{-1}$, kantong pipih terbentuk satu minggu lebih
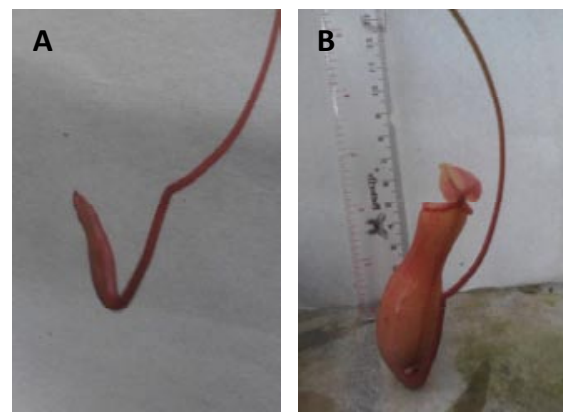

Gambar 2. Perkembangan kantong pada Nepenthes $\mathrm{x}$ ventrata. (A) kantong pipih, (B) kantong utuh

awal dibandingkan perlakuan lainnya. Sedangkan pada perlakuan lain daun baru yang terbentuk hanya menghasilkan sulur yang memanjang dan belum terdapat indikasi bahwa akan membentuk kantong. Faktor adaptasi pada lingkungan baru dengan pemberian perlakuan menjadikan alasan yang tepat jika modifikasi daun menjadi kantong belum terjadi.

Cepatnya waktu inisiasi kantong (waktu terbentuknya kantong pipih) tidak diikuti dengan cepatnya pembentukan kantong utuh. Waktu yang diperlukan kantong pipih untuk membentuk kantong utuh bervariasi dan tidak dipengaruhi oleh perlakuan pemupukan (Gambar 4).

Hingga 12 MSP hanya pada 3 perlakuan yakni kontrol, NPK 32-10-10 $1 \mathrm{~g} \mathrm{~L}^{-1}$ (C2K2), dan NPK 1055-10 0.5 $\mathrm{g} \mathrm{L}^{-1}(\mathrm{C} 3 \mathrm{~K} 1)$ yang telah membentuk kantong utuh. Perlakuan NPK 6-30-30 dengan konsentrasi $2.0 \mathrm{~g}$ $\mathrm{L}^{-1}$ yang membentuk kantong pipih paling cepat belum membentuk kantong pada 12 MSP. Pada perlakuan NPK 10-55-10 dengan konsentrasi $0.5 \mathrm{~g} \mathrm{~L}^{-1}$ (C3K1), persentase kantong utuh yang terbentuk dari kantong pipih lebih tinggi jika dibandingkan kontrol. Pada perlakuan kontrol banyak terbentuk kantong pipih namun hanya sedikit (20\%) yang berhasil berkembang

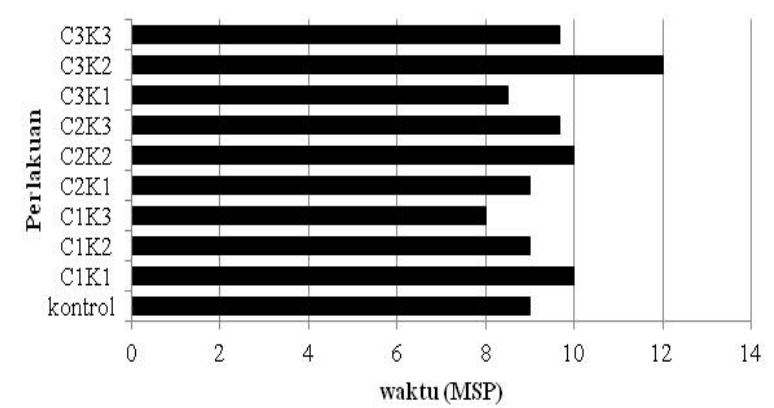

Gambar 3. Waktu (MSP) tanaman Nepenthes $x$ ventrata membentuk kantong pipih. 


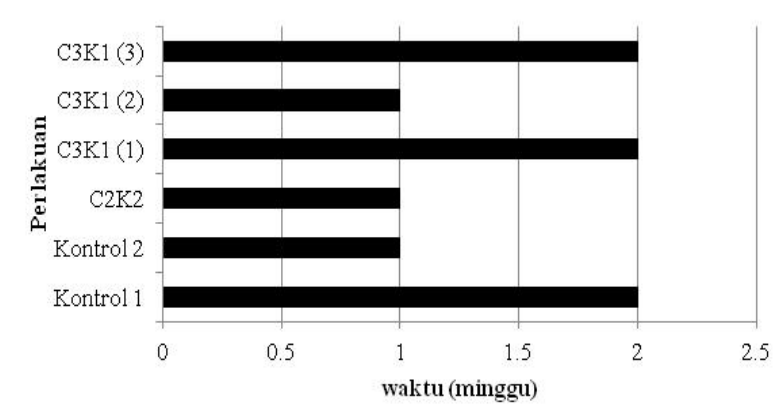

Gambar 4. Waktu pembentukan kantong dari kantong pipih pada Nepenthes $\mathrm{x}$ ventrata

menjadi kantong utuh pada 12 MSP (Tabel 2). Pada habitat aslinya, kondisi kekurangan hara memacu Nepenthes membentuk kantong agar dapat memperoleh hara dari serangga yang terperangkap. Hasil penelitian ini menunjukkan bahwa kondisi kekurangan hara dapat meningkatkan pembentukan kantong pipih (inisiasi kantong). Perkembangan kantong pipih menjadi kantong utuh tampak terhambat oleh kondisi kekurangan hara.

Karena pada 12 MSP kantong utuh hanya terbentuk pada tiga perlakuan (kontrol, NPK 3210-10 $1 \mathrm{~g} \mathrm{~L}^{-1}$; C2K2, dan NPK 10-55-10 $0.5 \mathrm{~g} \mathrm{~L}^{-1}$; C3K1), maka pengamatan terhadap kualitas kantong hanya dilakukan pada kantong yang telah terbentuk. Perkembangan kantong tampak tidak bertambah lagi pada umur 5 minggu setelah terbentuknya kantung pipih. Diameter kantong utuh yang diukur pada perut kantong berukuran $\pm 6 \mathrm{~cm}$ (Gambar 5A) sedangkan

Tabel 2. Inisiasi kantong hingga 12 MSP

\begin{tabular}{|c|c|c|c|c|c|}
\hline \multirow[t]{3}{*}{ Perlakuan } & \multicolumn{3}{|c|}{ Jumlah kantong pipih } & \multirow{3}{*}{$\begin{array}{c}\text { Jumlah } \\
\text { kantong } \\
\text { pada } \\
12 \\
\text { MSP }\end{array}$} & \multirow{3}{*}{$\begin{array}{c}\text { Persentase } \\
\text { sulur } \\
\text { menjadi } \\
\text { kantong } \\
\text { pada } 12 \text { MSP }\end{array}$} \\
\hline & 8 & 10 & 12 & & \\
\hline & MSP & MSP & MSP & & \\
\hline kontrol & 3 & 9 & 10 & 2 & 20.00 \\
\hline C1K1 & 0 & 2 & 3 & 0 & 0.00 \\
\hline $\mathrm{C} 1 \mathrm{~K} 2$ & 0 & 2 & 2 & 0 & 0.00 \\
\hline $\mathrm{C} 1 \mathrm{~K} 3$ & 1 & 4 & 2 & 0 & 0.00 \\
\hline $\mathrm{C} 2 \mathrm{~K} 1$ & 0 & 3 & 3 & 0 & 0.00 \\
\hline $\mathrm{C} 2 \mathrm{~K} 2$ & 0 & 3 & 7 & 1 & 14.29 \\
\hline $\mathrm{C} 2 \mathrm{~K} 3$ & 1 & 4 & 7 & 0 & 0.00 \\
\hline $\mathrm{C} 3 \mathrm{~K} 1$ & 2 & 3 & 6 & 3 & 50.00 \\
\hline $\mathrm{C} 3 \mathrm{~K} 2$ & 0 & 0 & 1 & 0 & 0.00 \\
\hline $\mathrm{C} 3 \mathrm{~K} 3$ & 0 & 6 & 6 & 0 & 0.00 \\
\hline
\end{tabular}

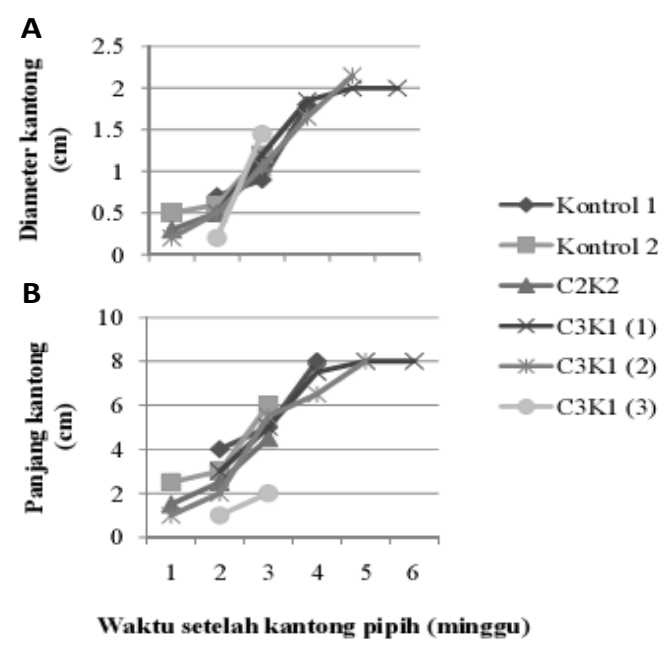

Gambar 5. Perkembangan kantong Nepenthes $x$ ventrata. (A) diameter dan (B) panjang kantong

panjang kantong berkisar antara 7-8 $\mathrm{cm}$ (Gambar 5B) pada saat kantung berumur 5 minggu setelah terbentuknya kantung pipih.

Walaupun tidak berpengaruh terhadap pertumbuhan vegetatif dan perkembangan kantong, perlakuan pemupukan berpengaruh pada perubahan warna pada kantong Nepenthes x ventrata (Gambar 6). Kantong yang terbentuk pada tanaman tanpa penambahan pupuk (kontrol) memiliki warna hijau kekuningan, sedangkan kantong yang terbentuk pada tanaman dengan aplikasi pemupukan berwarna kemerahan.

Hernawati dan Akhriadi (2006) menyatakan bahwa Nepenthes yang tidak mendapatkan hara akan membentuk yang berwarna lebih cerah dibandingkan
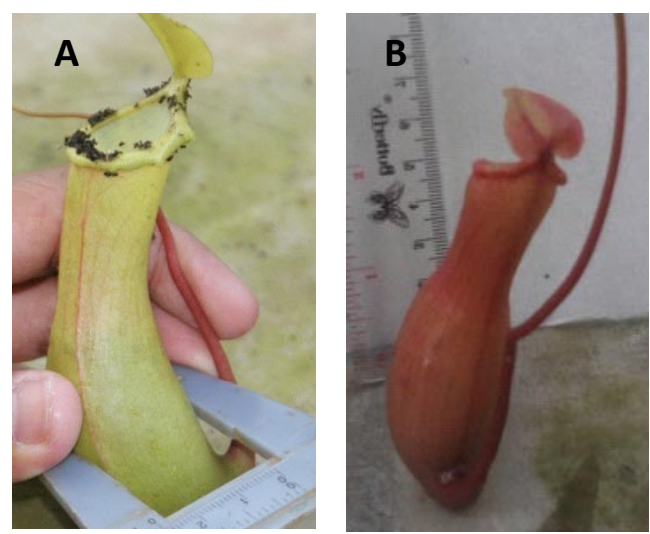

Gambar 6. Perbedaan warna kantong Nepenthes $x$ ventrata pad (A) perlakuan kontrol dan (B) perlakuan pemupukan NPK 10-55$100.5 \mathrm{~g} \mathrm{~L}^{-1}$ 
dengan yang mendapat cukup hara. Warna kekuningan yang lebih cerah pada tanaman yang kekurangan hara akan lebih menarik serangga. Hasil penelitian ini memberikan indikasi bahwa aplikasi pemupukan dapat memberikan warna kemerahan pada Nepenthes $\mathrm{x}$ ventrata yang cenderung kurang menarik di habitat aslinya, sehingga meningkatkan kualitas tanaman Nepenthes sebagai tanaman hias pot.

\section{KESIMPULAN}

Aplikasi pupuk majemuk tidak berpengaruh terhadap pertumbuhan vegetatif Nepenthes $x$ ventrata. Perlakuan pemupukan dapat meningkatkan persentase terbentuknya kantong utuh dari kantong pipih dibandingkan tanpa pemupukan. Aplikasi pemupukan juga dapat menghasilkan kantong dengan warna kemerahan yang memberikan nilai tambah pada Nepenthes $\mathrm{x}$ ventrata sebagai tanaman hias.

\section{UCAPAN TERIMA KASIH}

Penulis menyampaikan terima kasih kepada Muhammad Suska, pemilik Suska Nursery untuk bantuan penyediaan bahan penelitian dan diskusi selama penelitian berlangsung.

\section{DAFTAR PUSTAKA}

Adamec, L. 1997. Mineral nutrition of carnivorous plants: a review. Bot. Rev. 63: 273-299.

Adlassnig, W., M. Peroutka, H. Lambers, I.K. Lichtscheidl. 2005. The roots of carnivorous plants. Plant Soil 274: 127-140.

Aminifard, M.H., H. Aroiee, H. Fatemi, A. Ameri, S. Karimpour. 2010. Responses of eggplant (Solanum melongena L.) to different rates of nitrogen under field conditions. J. Central. Europian Agric. 11:453-458.

Budiana, N.S. 2007. Memupuk Tanaman Hias. Penebar Swadaya. Depok.
Clarke, C. 1997. Nepenthes of Borneo. Natural History Publications. Sabah, Malaysia.

Hernawati, P. Akhriadi. 2006. A Field Guide to the Nepenthes of Sumatra. Pili NGO Movement. Bogor.

Mansur, M. 2007. Keanekaragaman jenis Nepenthes (kantong semar) dataran rendah di Kalimantan Tengah. Berita Biologi 8: 335-339.

Osunkoya, O.O, S.D. Daud, B. Di-Giusto, F.L. Wimmer, T.M. Holige. 2007. Construction cost and physicochemical properties of the assimilatory organs of Nepenthes species in Northern Borneo. Ann. Bot. 99: 895-906.

Pavlovic, A., L. Singerova, V. Demko, J. Santrucek, J. Hudak. 2010. Root nutrient uptake enhances photosyntetic assimilation in preydeprived carnivorous pitcher plant Nepenthes talangensis. Photosynthetica 48: 227-223.

Phillips, A., A. Lamb, C.C. Lee. 2008. Pitcher Plants of Borneo. Natural History Publications. Sabah, Malaysia.

Rice, B.A. 2009. Looking for horticultural effects of SUPERTHRIVE ${ }^{\mathrm{TM}}$ on Nepenthes. Carnivorous Plant Newslett. 38:24-27.

Schulze, W., E.D. Schulze, J.S. Pate, A.N. Gillison. 1997. The nitrogen supply from soils and insects during growth of the pitcher plants Nepenthes mirabilis, Cephalotus follicularis, and Darlingtonia californica. Oecologia 112: 464-471.

Wang, C. W. 2007. Nepenthes Enzymes. Proceedings of the 2007 Sarawak Nepenthes Summit. Sarawak Forestry Corporation, Sarawak. 